\begin{abstract}
Dispersion in pay is lower among union members than among non-unionists. This reflects two factors. First, union members and jobs are more homogeneous than their non-union counterparts. Second, union wage policies within and across firms lower pay dispersion. Unions' minimum wage targets also truncate the lower tail of the union distribution. There are two major consequences of these egalitarian union wage policies. First, the return to human capital is lower in firms which recognise unions than in the unorganised sector. Second, unions compress the wage structure by gender, race and occupation.
\end{abstract}

This paper was produced under the 'Future of Trade Unions in Modern Britain' Programme supported by the Leverhulme Trust. The Centre for Economic Performance acknowledges with thanks, the generosity of the Trust. For more information concerning this Programme please e-mailn.ali1@lse.ac.uk. 


\section{Unions and the Sword of Justice: Unions and Pay Systems, Pay Inequality, Pay Discrimination and Low Pay}

David Metcalf, Kirstine Hansen and Andy Charlwood 
Series Editor: Graham Ingham

Published by

Centre for Economic Performance

London School of Economics and Political Science

Houghton Street

London WC2A 2AE

(C) D. Metcalf, K. Hansen and A. Charlwood, submitted February 2000

ISBN 0753013673

Individual copy price: $£ 5$ 


\section{Unions and the Sword of Justice: Unions and Pay Systems, Pay Inequality, Pay Discrimination and Low Pay}

\section{David Metcalf, Kirstine Hansen and Andy Charlwood}

1. Introduction 1

2. Union Wage Policies 2

2.1 Within establishments 2

2.2 Across workplaces and firms 4

$\begin{array}{lll}2.3 & \text { Minimum wage } & 7\end{array}$

2.4 Summary: our propositions 8

3. Data 8

4. Results and Discussion $\quad 10$

4.1 Unions and payment systems 10

4.2 Unions and the distribution of earnings 11

4.3 Unions and the incidence of low pay 12

4.4 Unions and the pay structure 14

5. Summary and Conclusion 16

$\begin{array}{ll}\text { Tables } & 18\end{array}$

$\begin{array}{ll}\text { Appendix } & 27\end{array}$

References $\quad 32$

The Centre for Economic Performance is financed by the Economic and Social Research Council. 


\section{Acknowledgements}

Helpful comments on an earlier version by the following colleagues are gratefully acknowledged: Sue Fernie, Rafael Gomez, Ed Heery, John Kelly, Steve Machin and participants at the CEP Labour Workshop. Bob McNabb and Keith Whitfield kindly recalculated some of their original estimates of associations between unionisation and low pay and these are reported in Tables 7 and 8.

David Metcalf, Kirstine Hansen and Andy Charlwood are at the Centre for Economic Performance, London School of Economics. 


\title{
Unions and the Sword of Justice: Unions and Pay Systems, Pay Inequality, Pay Discrimination and Low Pay
}

\author{
David Metcalf, Kirstine Hansen and Andy Charlwood
}

\section{Introduction}

Throughout most of the twentieth century trade unions have been an important force tempering the inequality of the distribution of pay. At the beginning of the century the Webbs (1902) emphasised the key role of the 'common rule' and 'rate for the job' in unions' wage policies. In the middle of the century - in the years after World War II - Clegg (1970) reports "Britain was well on the way to a system of industry-wide regulation of all aspects of industrial relations" (p.206) such that the same job had similar pay among all firms in the same industry. In the 1960s and 1970s when the locus of collective bargaining gradually decentralised from industry to the firm or workplace, shop steward combine committees sought to pursue this egalitarian union role: "Their most universal function is the exchange of information about pay and conditions but sometimes they go beyond this to agitate for equalisation of pay" (Clegg 1970 p.265). Metcalf (1982) presents evidence that confirms that, consequently, pay dispersion was lower among union members than their non-union counterparts in the late 1970s.

Since 1980 there have been profound changes to our system of industrial relations. The labour market has been deregulated as a consequence of the legislative onslaught against unions, more intense produce market competition and historically high unemployment levels. One result of deregulation is a halving in the coverage of collective bargaining - described by Phelps Brown (1990) as the "counter-revolution of our time" - coupled with the near abandonment of industry-wide agreements in the private sector (see Metcalf, 1999 for more details). The upsurge in the number of cases of union derecognition by management (Brown et al., 1998), outlawing the closed shop, and complete abandonment of minimum wage protection between 1993 and 1998 suggests that it is again time to take stock of the effect of trade unions on the distribution of earnings.

Our aim is to provide a definitive statement of the links between trade unions and the earnings distribution around the millennium. In Section 2 union wage policies are discussed and summarised in the form of six propositions. Data sources are set out in Section 3. The Labour Force Survey provides very full detail on individuals' pay and characteristics, while the 1998 Workplace Employment Relations Survey has extensive details on industrial relations in a nationally representative sample of over 2000 workplaces and further information on over 28000 workers employed in these workplaces. Results are set out in Section 4. This section contains evidence on links between unionisation and payment systems, the distribution of earnings, the returns to human capital, the incidence of low pay and any discrimination against women, blacks and those with health problems. Summary and conclusions are presented in Section 5. 
There have been a number of recent, very thorough, studies which test for the impact of unions on the distribution of pay in the overall economy (see e.g. Bell and Pitt, 1998 and Gosling and Machin, 1995). Their particular focus is the contribution to the widening of the earnings distribution over the last two decades made by the near halving of union membership. By contrast, our focus is comparisons between the unorganised and organised sectors of the labour market at a point in time. We pay much greater attention to the industrial relations strategies and tactics underpinning any differences between the two segments of the labour market and broaden the discussion out to include payment systems, low pay and discrimination as well as just the distribution of earnings.

Before turning to the body of the paper one interesting conceptual issue needs addressing. Union membership has haemorrhaged from around 12 million in 1980 to some 7 million presently. The number of workers covered by collective bargaining has also fallen dramatically. However, union membership and collective bargaining coverage are not the same thing. Table 1 presents the evidence. One quarter of employees are both union members and covered by collective bargaining. But $10 \%$ of employees are free riders - their pay and conditions are determined by collective bargaining but they are not union members. A further $6 \%$ are in a union but their pay is not bargained. Some of this latter group are teachers and nurses whose pay is set by arbitration and others will, for example, have retained their union membership when their employer derecognised the union. The largest group $(59 \%)$ are neither union nor covered by collective bargaining. In our empirical work should we analyse the effects of collective bargaining coverage which takes account of the large number of free riders who benefit from union activity, or union membership - because a surprisingly large number of employees are members even though they are not covered by collective bargaining? There is no "right" answer to this question. Therefore in the text we mainly report the links between union membership and pay and in the appendix counterpart tables are presented replacing membership with collective bargaining coverage.

\section{Union Wage Policies}

A stylised industrial relations fact is that pay dispersion among unionised workers is lower than the spread among their non-union counterparts. For example Machin (1999) states: "Trade unions have traditionally been seen as defenders of egalitarian pay structures. This is reflected in 'equal pay for equal work' notions and the standardisation of pay setting mechanisms, often in the form of rigid pay scales attached to jobs rather than individuals." But it is worth setting out the three routes to this greater equality of pay in the organised sector in a little more detail.

First, unions reduce pay dispersion within establishments. Second, union wage policies lead to a narrower wage dispersion in the organised compared with the unorganised sector. However, the strength of this channel, which operates across firms and workplaces, has been weakened as collective bargaining has become more decentralised. Third, unions truncate the bottom tail of the pay distribution by operating a de facto minimum wage policy in the organised sector whereas there was no minimum wage protection for unorganised employees at the time (Autumn 1998) the data was collected for this study. These routes to predicted lower pay dispersion in the organised sector will be considered in turn.

\subsection{Within establishments}

Within establishments unions aim to reduce pay dispersion via two operational rules. First, unions prefer a single rate of pay for each occupational group whereas in non-union firms 
with individual pay determination supervisors decide pay levels within a range. Procedural agreements between unions and management often establish fixed differentials between occupational groups. Second, unions prefer seniority-based progression of rates up to a maximum over individual merit pay.

Union preferences for reduced differentials within firms stem from unions' desire for objective standards, organisational considerations and workers solidarity. Unions would sooner opt for impartial standards, where pay goes with the job, because of concerns about favouritism, discrimination and the measurement of the "true" contribution where pay is subjectively related to the "merit" of the individual. Next, in nearly all firms median pay is less than mean pay. A median voter model of union organisation suggests therefore, that over half of employees will favour redistribution towards the lower paid. In workplaces where multiple unions are present and recognised single table bargaining has become the norm (see Cully et al., 1999). Where single table bargaining operates, procedural agreements between unions allocate seats on the joint negotiating committee according to the size of union membership. The joint negotiating committee presents a pay claim for all employees, the details of which have been agreed between the unions beforehand. Therefore the median voter model will also operate in workplaces with multiple unions but single table bargaining. For example, the procedural agreement between the management of the Rosyth Dockyard and the six recognised non-managerial unions states: "In matters affecting Pay and Conditions of employment where a workplace ballot is conducted the majority decision reached will be accepted by all union members" (Rosyth Royal Dockyard, 1992). Finally, workers' solidarity is likely to be greater when workers receive roughly the same pay than when they get different amounts.

These union preferences have long been remarked upon. Forty years ago Slichter and his colleagues (1960) concluded that within firms the role of unions "clearly has been one of minimising and eliminating discriminatorily judgement-based differences in pay for individuals employed in the same job" (quoted in Freeman, 1982). Most recently Brown et al. (1998) present detailed case study evidence from 32 matched firms, some which had always had collective bargaining, some which derecognised unions and moved from collective bargaining to individual determination, and some which had always used individual contracts. Their findings could not be more unambiguous. For example: "For many firms, the advantage of breaking away from an existing structure of collective bargaining was to increase the dispersion of pay, both within grades and between hierarchical levels". Further "there was a greater tendency towards linking pay rises to individual performance in derecognising firms than in those retaining collective bargaining. Employers tended to gain substantial discretion to set individual pay by open ended appraisal procedures" (p.i). And in those firms without collective bargaining, where pay still goes with the job: "One consequence of management's increased authority is that job descriptions can be left vaguer because employees can be expected to comply with greater flexibility of working at management's discretion" (p.28).

British unions have normally been antagonistic to subjective individual merit Performance Related Pay schemes and guarded about company-wide PRP schemes like profit sharing which cause employees to share business risks with capital. Heery and Warhurst (1994) surveyed the 61 largest trade unions and staff associations in Great Britain. They found that the introduction or extension of merit pay schemes had been the cause of industrial disputes in a number of sectors including the civil service, education, banking and television. The union responses $(n=61)$ to merit pay were: 


\begin{tabular}{|l|r|}
\hline \multicolumn{1}{|c|}{ Policy } & \% \\
\hline Opposed and committed to resistance & 26 \\
Opposed but prepared to accept & 43 \\
Pragmatic, neither opposed nor in favour & 16 \\
Supportive, ready to accept & 7 \\
Organisation advocates merit pay & 2 \\
No policy & 7 \\
TOTAL & $\mathbf{1 0 0}$ \\
\hline
\end{tabular}

Heery (2000) concludes from this and other evidence that "this kind of payment system [merit pay] is associated with non-unionism and derecognition". A graphic example of union opposition to merit pay comes from the Communication Workers Union who state: "The CWU and the union movement generally have consistently opposed the introduction of PRP schemes and the notion that they improve overall performance. The principle that employees can collectively bargain with their employer over pay lies at the heart of the union movements opposition. Where pay is determined by a set of performance indicators, rather than through collective bargaining, trade unions and the workers they represent lose vital influence over pay and related matters" (CWU, 1999).

Profit-related pay schemes and Employee Share Ownership Schemes can, in principle, cause fluctuations in pay consequent on risk sharing between labour and capital. Unions have therefore typically been cautious of such schemes. However, such schemes have normally attracted generous income tax breaks so unions do not automatically oppose their introduction. A recent Trade Union Congress paper stated: "In the past the TUC has always favoured collective forms of employee ownership. However, unions have also negotiated pragmatically on the role of employee share schemes in the overall pay package. The general policy stance might be described as engaged scepticism with the object of delivering the best possible outcome for members" (TUC, 1999a). Academic research has informed and supported this shift in policy. For example, Pendleton et al. (1995) found no evidence of weakened union organisation where profit sharing or ESOS had been introduced.

\subsection{Across workplaces and firms}

At the turn of the century, the Webbs (1902) introduced the concept of 'the common rule' into the vocabulary of industrial relations and used it to define trade union objectives. The fixing of a standard pay rate - the rate for the job - was the pivotal common rule (see Flanders, 1970). Similarly in the United States "wage standardisation within an industry or local product market is the most likely heralded union wage policy" (Slichter et al., 1960).

Pursuit of the rate for the job narrowed pay dispersion within the organised sector. Freeman and Medoff (1984) suggest two rationales for this common rule. First, when firms compete in the same market, both employer and worker interests can be expected to favour a standard rate. The firm does not want a labour contract that is more expensive than its competitors. And for the worker, it takes wages out of competition - there will be no undercutting. Second, union solidarity may be more difficult to maintain if some workers are paid markedly more than others for the same job.

The strength of this common rule has ebbed away as the locus of collective bargaining in the private sector has switched from national multi-employer agreements to firm or workplace agreements. Around one quarter of private sector employees are covered by 
collective agreements (Cully and Woodland, 1998) of which only 1-in-10 are covered by national agreements. Consequently the dispersion of pay in the organised sector is likely to be higher now than it was two decades ago. Interestingly, an analogous proposition has recently been confirmed using cross country labour market evidence from OECD by Blau and Kahn (1996) who found that countries with decentralised bargaining had greater pay dispersion than those with centralised bargaining.

Nevertheless the organised sector is still likely to have less dispersion in pay, other things equal, than the unorganised. Gospel and Drucker (1998) show that in parts of printing, textiles and clothing, multi-employer bargaining still sets "a minimum safety net of terms and conditions". Further "national multi-employer regulation has survived in the construction sector. It has survived strongly in electrical contracting, where the relatively tight and comprehensive agreement later provided a model for engineering construction". Similarly, Jackson et al. (1993) describe union attempts to preserve an industry rate through patternbargaining in supermarket retail and textile manufacture.

Local bargaining replaced national bargaining in a whole range of sectors during the 1980s, including engineering, buses, banking, cotton, textiles, independent television, food retailing and manufacturing, docks, cement, newspapers, merchant shipping and wholesale meat (Brown \& Walsh, 1991). But even in these sectors where national bargaining has disintegrated and been replaced by local bargaining, unions' own internal organisation permit (even encourage) pay comparison. We can identify four mechanisms by which this comparison takes place: (i) the role of the unions' research departments and publications; (ii) collective bargaining courses run by unions' education departments; (iii) sectoral and industrial meetings and conferences organised within and between unions; (iv) the role of the full-time official. Further, the reduction in the number of unions due to mergers, and the subsequent concentration of the majority of union members into a handful of large unions has strengthened (i) and (ii) recently.

All major trade unions now have research departments whose main function is to provide research support for collective bargaining. Key information collated includes: data on company performance, rises in the cost of living and comparative data from pay settlements made by major companies and employers. Most unions supplement their own research-gathering facilities by subscribing to publications from specialist pay research companies like Incomes Data Services and Industrial Relations Services. This research is then disseminated through union publications e.g. MSF Report, AEEU Review, GMB Bargaining Brief and UNISON Bargaining Update. These are all specialist publications aimed at unions' shop stewards and reps and they contain detailed briefings on issues like changes to health and safety law and new employment legislation. They also contain information to use in pay bargaining such as details of settlements in other companies. Further, in many unions reps have access to up-to-the-minute information on the latest settlements being agreed within the industry via computer-held databases.

All the major unions have their own education departments. The TUC through its regional structure and, working in partnership with local further education colleges, organises NVQ accreditation courses for about 28,000 official representatives and shop stewards each year. Such courses are a key way in which unions train activists to fulfil their role as stewards or officials. In addition to training in individual representation and employment law, training in the conduct of collective bargaining is a key component of each course. This includes substantive information on the arguments to present in making pay claims; for example, changes to the cost of living, levels of previous pay rises, the current going rate for pay settlements both within the industry and more broadly across the economy, and the performance of the company. Only this last variable is likely to vary markedly from workplace to workplace. 
Unions' internal representative structures have always reflected the organisation at an industrial level. Smaller unions are internally cohesive because they represent workers in a single occupation or industry; larger unions hold sectoral conferences and meetings. For example, the TGWU has a trade group structure where delegates from the different industries which make up the TGWU's membership come together for national bi-annual trade group conferences, and more regularly at a regional level. There even remain in existence interunion sectoral confederations from the era of sector bargaining. One example of this is the Confederation of Shipbuilding and Engineering Unions (CSEU) which holds an annual policy conference, continues to maintain a district structure (albeit now largely moribund) and national industry committees for aerospace, railways, shipbuilding and engineering (CSEU, 1999). The CSEU survives partly through union inertia, but also because single table bargaining is now the norm throughout the engineering industry, therefore an element of inter-union cooperation and coordination at a national level remains desirable. The role of these meetings in pay determination should not be underestimated just because they have no formal role in formulating pay claims. The networking and contacts built up among shop stewards in different companies and workplaces are an important factor in maintaining the idea of the rate for the job across companies and workplaces.

Even though most collective bargaining over pay in the private sector is decentralised and is carried out by shop stewards at company or workplace level WERS98 reports that 57\% of union reps who conduct local negotiations over pay do so with the assistance of a full-time union official (Cully et al., 1999). It is likely that the presence or contribution of union officials narrows the dispersion of settlements within the unionised sector compared with dispersion where workplace reps negotiate unilaterally. This results from the fact that the FTOs bargain with the same broad objectives from workplace to workplace and play an important role in shaping the preconceptions of what constitutes a "fair deal" among the reps and members.

The impact of the first two mechanisms are likely to have been strengthened by changes in union structure and organisation; most notably the concentration of union membership into a few very large unions due to union mergers. At the end of 1997 there were 233 listed trade unions in Great Britain, less than a fifth of the peak number of 1,384 in 1920 (Bland, 1999). Two thirds of union members are now in the nine largest unions, while the smallest 109 unions have fewer than 1000 members each. This change means that a high proportion of union activists and negotiators get the information on which they base their negotiations from a small number of sources.

Over half of union members work in the public sector and here the national rate for the job mainly survives. Well over one million nurses, teachers, doctors and dentists have national pay rates set by arbitration (Review Bodies). Some $0.3 \mathrm{~m}$ police and fire-fighters have national pay scales determined by indexation formulae. Other Local Authority employees (other than teachers, police and fire-fighters) total some $1 \mathrm{~m}$ workers and include education ancillaries, manuals, builders, engineers and white collar administrative, professional and technical employees. For these groups the Local Government Association the national voice of the 420 Local Authorities - states (1997): "Local government operates a comprehensive system of national pay bargaining. While the system is a voluntary one, in that local authorities are not obliged to follow national agreements, for the most part national agreements do apply" (para 4).

National bargaining remains the norm in other parts of the public sector too. This system covers, for example, over half a million health service ancillaries, prison officers who are nearly all employed by central government and workers in the remaining public corporations like the Post Office. 
Central government has gone furthest in moving towards decentralised bargaining, with many employees being segmented into Agencies like the Benefits Agency, Child Support Agency and the Information Technology Service Agency. But even here the Treasury still sets the parameters of the Agency-based negotiations. Further, recent evidence (Fernie and Metcalf, 1999) shows that the performance-related component of Agencies' collective agreements contributes a small fraction of total remuneration.

Large chunks of the economy moved from the public sector to the private sector through privatisation during the last two decades. These privatised companies can be split into two broad categories. First, those companies like British Petroleum, British Leyland and British Aerospace that operate within competitive product markets. Second, those such as British Telecom, gas, water, electricity and the railways, where the privatised companies continue to enjoy a monopolistic or near-monopolistic position within their own product market. Companies that operated in competitive product markets were usually covered by whatever type of national level bargaining operated within the industry. Since privatisation their bargaining behaviour has been typical of other firms within the same industry that were always part of the private sector. For example, British Aerospace abandoned national bargaining when industry wide engineering agreements came to an end in 1991. The company now conducts bargaining at the level of the business unit or plant in line with the rest of the unionised engineering sector.

The privatised utility companies and the railways have also shifted their bargaining culture away from public norms towards behaviour more typical of private companies. National bargaining across a whole industry (or in the case of BT and British Rail single firm organisations) has been replaced by bargaining at company or business unit level, and elements of merit pay have been introduced despite union opposition (see for example the view of the CWU in BT cited above). These changes mean that we can expect a widening of the pay distribution since privatisation, but continuing union recognition should prevent the pay distribution widening to the extent that we see in the non-unionised private sector.

\subsection{Minimum wage}

For most of the last century (till 1985) the union movement was hostile to the idea of a statutory national minimum wage (NMW), believing a NMW would undermine collective bargaining where it existed and inhibit its spread among unorganised workers. Instead unions operate a de facto minimum wage policy via collective agreements. In 1998 (year of empirical data for this study) there was no minimum wage protection in the unorganised sector so it is to be expected that, if unions are successful at truncating the bottom tail of their pay distribution, this too will contribute to lower pay dispersion for organised than unorganised workers.

The Local Government Association (1997) confirms this role of collective bargaining: "The lowest basic rate in our national agreement is $£ 4.00$ an hour [in 1997] i.e. this is the assimilation rate for the lowest graded adult (aged 18+) manual workers e.g. cleaners and catering assistants and the lowest pay point for adult clerical staff'. In 1997 around 1-in-6 local authority workers covered by collective bargaining received this minimum rate - a very noticeable spike in the pay distribution for such workers.

Individual unions operating collective agreements in the private sector confirm the importance they attach to truncating the distribution. For example the Transport and General Workers Union recently stated (1997): "Our active campaign for a $£ 4.00$ an hour minimum wage [in collective agreements]... has led to negotiated agreements raising basic wages to this level and beyond in a range of industries recently". It cites, for example, local agreements signed on behalf of industrial cleaners in London, knitwear operatives in Scotland 
and bar staff in Belfast. And national agreements with a similar impact cover cast stone and concrete workers, Ministry of Defence industrial civil servants, the building brick industry and the demolition industry. Similarly, the shop workers union USDAW, reflecting on its success in raising minimum pay levels among organised retail workers, stated (1997) that a NMW "will provide protection for the unorganised, who are the most vulnerable".

This important effect of collective agreements is confirmed by the detailed case studies into wage and employment contracts carried out by Brown and colleagues (1998) mentioned above. They conclude: "A central objective of some employers in individualising was to steepen the gradient of pay across the organisation, taking advantage of the potential for recruiting less skilled labour at lower rates than before".

\subsection{Summary: our propositions}

This discussion of union wage policies can be summarised in the form of six propositions:

Proposition 1. In setting pay, workplaces where unions are recognised will make greater use of objective criteria such as job classification and seniority. Non-union workplaces will make greater use of subjective performance appraisal and core competencies than unionised workplaces. This implies, in turn, that where contingent pay is used unionised workplaces will have schemes based on objective criteria - share options or profits - whereas non-union workplaces are more likely to use merit-based schemes.

Proposition 2. Pay dispersion in the organised sector will be lower than in the unorganised sector. This follows directly from the union impact inside the firm, the remnants of the common rule across private sector firms and its continuation in the public sector and the truncating of the lower tail of the pay distribution among organised workers.

Proposition 3. The move to decentralised bargaining - particularly in the private sector - will be associated with greater pay dispersion now than when collective bargains were mostly national multi-employer agreements.

Proposition 4. The discussion above supports Brown et al.'s (1998) contention that the gradient of pay will be "steeper" in unorganised than organised sectors. Another way of putting this is to say that the returns to extra human capital - experience, education qualifications and training - will be, on average, lower for union than non-union employees.

Proposition 5. There are two ways of looking at the incidence of low pay. Among workplaces, the likelihood of clusters of low pay is predicted to be lower where unions are recognised than where they are not. And among individuals, union members will have a lower probability of being low paid, other things equal, than non-union members.

Proposition 6. It is plausible that the de facto minimum wage role of unions means that the union mark-up will be higher for relatively low paid workers than for the higher paid. For example, higher for women than men, blacks than whites, those with health problems than the healthy and manuals compared with non-manuals. However, even if this is so it does not follow automatically that unions compress the wage structure between each such pair. That union effect also depends on the fraction of each group unionised. In the event, such rates of unionisation are almost identical for each group in the pair (e.g. women and men), so it is likely that unions do indeed narrow the wage structure.

\section{Data}

The propositions set out above are tested using data from the Labour Force Survey (LFS) and the 1998 Workplace Employment Relations Survey (WERS). The LFS is a quarterly survey of some 63000 households in the UK. All EU countries have their own Labour Force 
Surveys, containing comparable information, which allows comparisons to be made across Europe. The LFS was first conducted in spring 1973 and aimed to provide information on the UK labour market. Between spring 1973 and spring 1983 the survey was carried out every second year. In spring 1984 the survey became annual. And from spring 1992 onwards the survey was conducted quarterly; March-May, June-August, SeptemberNovember, and December-February.

In each quarter of the LFS there are five waves, each made up of roughly 12,000 households. Thus, in any quarter one wave of respondents will be interviewed for the first time, one wave for the second, one for the third, one for the fourth and one wave for the fifth and final time. About 30\% of LFS responses are proxy responses, that is the answers have been provided by another member of the same household if the respondent was unavailable.

Income questions were introduced to the LFS in winter 1992/3. But until winter 1997 income questions were only asked of respondents in their fifth wave. Since winter 1997 respondents have been asked about their income in both their first and final waves. For this research hourly wages were defined by dividing gross weekly pay by total usual hours worked plus usual hours of paid overtime. Those with wages under $£ 1$ an hour and over $£ 150$ an hour were dropped from the analysis. Also dropped were those aged under 18, over 59 (women) or 64 (men), full-time students and the self-employed. Questions concerning union membership have been available in the LFS every Autumn quarter since 1992.

The research reported here uses the Autumn 1998 LFS. This provides earnings information for a sample of over 16,000 people. Autumn 1998 was chosen because there was no statutory minimum wage protection then, important for testing Propositions 5 and 6 . The winter 1998/9 pay data would be affected as firms adjusted pay structures in anticipation of the NMW, introduced in April 1999.

Our second data source is the 1998 Workplace Employee Relations Survey (WERS98). (Cully et al, 1999 provide full details of the survey and information on previous surveys in 1980, 1984 and 1990). WERS98 collected detailed information from 2191 workplaces with ten or more employees - the largest survey of its kind in the world. 15.8 million people work in workplaces with ten or more employees, three quarters of employees in employment in Britain. Large workplaces were over-sampled, but the use of weighting variables allow results to be representative of all British workplaces with ten or more employees.

According to those responsible for the survey it aims to "examine what is, rather than what ought to be, the current situation [in employment relations]. It is uniquely well placed to do this, because of the manner in which the survey is founded, organised and conducted" (Cully et al., 1998:1). The sponsoring bodies are the Department of Trade and Industry, The Economic and Social Research Council, the Advisory, Conciliation and Arbitration Service and the Policy Studies Institute. The survey was designed by a small team from the sponsoring bodies in conjunction with leading academics in the field. The interviewing was conducted by Social and Community Planning and Research between October 1997 and June 1998.

WERS98 comes in three parts. The first part is a management questionnaire, completed by senior managers responsible for the management of employee relations in the workplace. The response rate for this section of the survey was $80 \%$. The second section is a worker representatives questionnaire: 950 worker representatives were interviewed, a response rate of $83 \%$ from workplaces with a worker representative. In a departure from previous WERS surveys, WERS98 also contains a short employee questionnaire. These questionnaires were distributed to 25 randomly chosen employees in each workplace. Completed questionnaires were returned by 28,323 employees, about two-thirds of those distributed. 
WERS98 contains a wealth of detail on pay levels and systems and collective representation, along with extensive information on workplace characteristics, allowing us to control for other factors that may influence pay systems and the distribution of pay. The section on representation at work contains information on three key areas. First, the type of relationship between management and unions; if the management recognises unions for collective bargaining, individual representation or neither. Second, the structure of workplace trade unionism - the extent of multi-unionism, and the unionisation levels among different occupational groups. Third, the strength of the union indicated by whether a pre or post-entry closed shop exists, and the percentage of employees that are union members. The section on payment systems and pay determination asks questions about different types of variable pay schemes present in the workplace; which occupational groups they are applied to; and the extent of participation in schemes like employee share ownership in the workplace. The worker representative questionnaire allows the responses in the management questionnaire to be verified. Overall the high response rates make information derived from WERS98 extremely reliable.

\section{Results and Discussion}

\subsection{Unions and payment systems}

Unionised workplaces differ markedly from non-union ones concerning the factors that influence pay levels among (full-time) employees in the largest occupational group (see Table 2). Unionised workplaces are more likely to pay according to the job and less likely to use performance appraisal and merit pay. This confirms our discussion of unions' preference for objective over subjective measures. Similarly, non-union workplaces are more likely to opt for a competency approach to pay than their union counterparts, the latter are more likely to use formal qualifications than are non-union workplaces.

Seniority influences pay in half of union workplaces but in only a quarter of nonunion ones. This demonstrates the importance of procedural justice in the organised sector. Seniority is a mechanism by which unions enforce non-arbitrary procedures for pay and promotion and so any pay differentials arising out of seniority-based systems are compatible with union goals. Although age-related pay is not common in either sector it is more likely to be found in non-union than union workplaces. This confirms recent evidence given to the Low Pay Commission in connection with the youth wage. The TUC (1999b) stated it "is strongly opposed to the lower rate for younger workers". By contrast the British Chamber of Commerce, representing smaller non-union companies stated that its members are "strongly in favour of lower youth minimum wages". The evidence in Table 2 supports Proposition 1 concerning the greater use of objective criteria in pay setting in unionised workplaces.

The association between union recognition and use of particular types of payment system is set out in Table 3. Two separate samples of workplaces were used - all workplaces and those in the private sector. This is because public sector employees are ineligible for certain contingent pay such as share ownership schemes and profit related pay. Many controls were included (see note to Table 3) because use of different payment systems may be influenced by factors such as workplace size or the characteristics of the labour force.

For the whole sample union recognition is associated with a lower incidence of individual or group based performance related pay schemes (which include merit pay). But this seems to reflect less use by public sector workplaces because there is no such association for the private sector sample. Within the private sector unionised workplaces are more likely 
to make use of employee share ownership schemes than their non-union counterparts. This partly reflects union preferences for objective schemes. It also suggests a pragmatic response to such schemes: the value of the tax breaks provided by the Treasury to promote the use of such schemes offsets the implied risk-sharing element inherent in the schemes. There is no association between unionisation and use of profit sharing schemes or use of any contingent pay schemes.

These results are consistent with Proposition 1 but provide only weak support for that proposition. When recognition is replaced by density similar links occur. The results are quite similar to those of Burgess (1999) who used the 1990WIRS and states that: "strong unions make a merit pay (subjective assessment) scheme less likely.... This favouring of objective over subjective criteria, and favouring of collective rather than individual schemes does not seem surprising".

\subsection{Unions and the distribution of earnings}

Union members earn more than non-union members and their pay distributions are more concentrated than the corresponding distributions for non-unionists. The evidence is set out in Table 4. The fraction of each group unionised - around one third - is remarkably consistent. In each group union members have higher hourly pay than their non-union counterparts. But the dispersion in pay, measured by the coefficient of variation (standard deviation divided by the mean) is, in every case, lower among union members than it is among non-unionists. For example, the average hourly pay of female union members is $£ 8.37$, over $£ 2$ higher than that for non-union females, but the coefficient of variation for union members is only 0.482 compared with 0.672 for non-unionists.

This evidence suggests that union wage policies such as common rates and lack of enthusiasm for contingent pay causes lower dispersion in the pay distribution among union members. But, of course, this neglects the composition of employees and jobs. It may well be that people and jobs in the unionised sector of the economy are more homogenous than those in the non-union sector and that this is the reason why the union wage distribution is narrower than the non-union distribution. This possibility is investigated in Table 5.

Three measures of the dispersion of log earnings are presented, the standard deviation, the $90^{\text {th }}$ percentile minus the $10^{\text {th }}$ percentile and the variance. Consider initially the raw earnings data. In every case, on all three dispersion indicators, the union pay distribution is more concentrated than the non-union pay distribution, confirming the information in Table 4.

Now consider the dispersion in the residuals from a regression equation which permits controls for the heterogeneity of people and jobs between the union and non-union sectors. The control variables are set out in the notes to the table and include age, qualifications, workplace size, industry, and (most importantly) occupation - to control for the lower incidence of union membership at the top and bottom of the pay distribution. Two strong findings occur. First, considerable pay dispersion remains even when controls are included. The dispersion in the residuals is around two thirds the dispersion in the raw data. (This is simply another way of saying that earnings functions leave much of the variance in pay unexplained.) Second, it remains the case that, on every measure of dispersion, even when we essentially compare homogeneous employees in similar workplaces and jobs, that pay dispersion is lower for union members than for non-union employees. Thus union wage policies do matter - the lower dispersion in pay among unionists is not just because they are more similar than non-unionists. This confirms Proposition 2.

It was predicted in Section 2 that, while pay dispersion would be lower in the organised than the unorganised sector, the move to decentralised bargaining - particularly in 
the private sector - will have caused dispersion to increase among union members. This prediction is strongly supported by the evidence. Metcalf (1982) reported the coefficient of variation among organised (and unorganised) workers for 1978, which was typically only some two thirds as large as the corresponding coefficient of variation two decades later reported in Table 4. Thus the move away from national bargaining and the common rule rate for the job is associated, not surprisingly, with greater pay inequality in the organised sector. This confirms Proposition 3.

One reason that the dispersion in pay among unionised workers is lower than among their non-union counterparts is because in unionised workplaces pay is based more on jobs and less on individual characteristics. Hence the characteristics of workers which raise pay have a smaller effect in unionised workplaces and, in turn, inequality is smaller in union than in non-union workplaces.

Consider, for example, the payoff to extra human capital - experience and qualifications - set out in Table 6. The returns to labour market experience (proxied by age) indicate that, as compared with those aged under 25 , prime age union members earn $37 \%$ more while prime age non-union members earn $48 \%$ more. The same pattern holds for women but the absolute gap is less pronounced.

Similarly, for men, the returns to higher qualifications are greater and the profile is steeper among the non-union group than for union members. For example a union member with A-levels as his highest qualification earns $34 \%$ more than a member with no qualifications whereas the corresponding non-union man is paid 53\% more. These results confirm Proposition 4. However, the same pattern does not hold for females, possibly because many of the higher paid female jobs like teachers and nurses are in the more highly unionised public sector.

These lower returns to human capital in the organised sector may well be a cause for concern for trade unions. It is possible that workers sort themselves, or are sorted by their potential employers, such that the more able prefer to work in non-union firms where they can get a higher payoff to their costly investment in human capital. Booth and Frank (1999), for example, show that men gain only $5 \%$ from the use of performance-related pay in the union sector, versus $12 \%$ in the non-union sector.

Returns to workplace size are also presented in Table 6. The payoff to being in a larger workplace (50+ employees) is some three times higher for non-unionists than for union members. For example, as compared with those in small workplaces with fewer than 25 employees, non-union women earn $15.6 \%$ more whereas union members earn only $4.4 \%$ more. There are a number of possible explanations for the fact that the employer size wage effect is larger in the non-union sector. For example it is generally held (Lazear 1986) that it is more costly to monitor effort in larger than in smaller workplaces. Possibly unionised employers plump for greater supervision in large workplaces whereas those without unions adopt efficiency wage policies. Alternatively, Green et al. (1996) present a monopsony model where "we would expect unions to reduce the size-wage effect because unions tend to raise wages but an upper bound on wages is given by the marginal product. Hence wages get squashed into a smaller gap.” (p.440.)

\subsection{Unions and the incidence of low pay}

It was predicted in Section 2 that union recognition would truncate the bottom tail of the wage distribution. We are very fortunate because the fourth Workplace Employment Relations Survey (WERS 1998) contained questions on low pay for both workplaces and individuals. Workplace managers were asked about the fraction of their employees earning under $£ 3.50$ an hour at the time of the survey (mid 1998). This information is available 
separately for full-time and part-time workers. The employee survey asked about actual weekly pay and hours and this permits an analysis of the probability of earning below $£ 3.50$ per hour. Such a benchmark is very convenient because it is equivalent to the $£ 3.60$ an hour national minimum wage which came into force in April 1999.

Initial cross tabulations from the establishment data from WERS confirm that union recognition is associated with a lower incidence of low pay (Cully et al. 1998):

$\%$ of workplaces with $25 \%$ or more employees earning less than $£ 3.50$ per hour

No union presence 16

Union present, no recognition 9

Unions recognised

Thus a mere 1-in-50 workplaces recognising have under a quarter of their workforce earning below $£ 3.50$ per hour but the incidence of such clusters of low pay is eight times greater in non-union workplaces. These cross tabulations are informative but it is necessary also to control for factors other than union recognition which influence pay, including human capital, product market competition etc. McNabb and Whitfield (1999) have undertaken just such a detailed exercise using WERS98 data.

Evidence on the link between unionisation and the incidence of low pay is set out in Tables 7 and 8 where the unit of observation is, respectively, workplaces and individuals. Consider workplaces first. The sample is 1106 workplaces in the trading sector which are a nationally representative sample of workplaces with 10 or more employees. The dependent variable is the percentage of employees earning below $£ 3.50$ an hour, which has a mean of $10.5 \%$. The unionisation variables are recognition, coverage of collective agreements and union membership at the workplace but no recognition. The control variables are set out in note 3 to Table 7 and include workplace, workforce and product market controls. Because the incidence of low pay is left-censored with a significant proportion of observations having a zero incidence of low pay the appropriate form of analysis is a Tobit equation.

The table provides evidence on the coefficients from the Tobit equation and the marginal effects. The coefficient indicates whether or not the variable is significantly associated with the incidence of low pay. The marginal effect indicates the magnitude of any such association. Consider the coefficients first. It will be seen that union recognition and coverage above $60 \%$ both reduce the incidence of low pay. By contrast workplaces which have one or more union members but which do not recognise unions have a higher incidence of low pay than other workplaces. This might reflect, for example, de-recognition of unions by low paying firms. It is noticeable that it is links between unionisation and the incidence of low pay among full-time workers which drives these findings - none of the coefficients on the union variables are significant when the dependent variable is confined to part-time employees.

The marginal effects indicated that union recognition reduces the incidence of low pay, other things equal, by 3.9 percentage points. This is a substantial effect because the mean percentage earning below $£ 3.50$ is $10.5 \%$. Where coverage of collective bargaining is above $60 \%$ this reduces the incidence of low pay by a further 3.8 percentage points. Thus recognition coupled with extensive coverage $(60 \%+)$ reduces the percent low paid by nearly 8 percentage points or some three-quarters of the mean. 
WERS also collected information on the pay of 19598 individuals of whom $3.4 \%$ earned below $£ 3.50^{1}$. For the sample as a whole both union recognition and union membership lower the likelihood of being low paid (but the depth of coverage in the workplace does not). For men it is union membership that matters, whereas for women the important thing is working in a workplace with recognised unions. This distinction reflects the fact that lower paid workers gain more from union recognition than the higher paid (see below). The marginal effects show the key role unions play in reducing the probability of low pay. Membership reduces that probability by 0.6 percentage points - from the mean of $3.4 \%$ to $2.8 \%$ - and recognition by 0.8 percentage points. Taken together recognition and membership lower the probability of low pay by over 1 percentage point (in this model the marginals are not additive and the figure is lower than $0.6+0.8=1.4$ percentage points) or one third.

Taken together the results in Tables 7 and 8 unambiguously support Proposition 5. To varying degrees union membership, union recognition and extensive collective bargaining coverage each reduce the incidence of low pay. This important effect of trade unions will be somewhat attenuated by the introduction of the national minimum wage (NMW) in 1999 but it is clear that, prior to the NMW, unions played an important role in truncating the lower tail of the pay distribution.

\subsection{Unions and the pay structure}

The impact of unionisation on the pay structure by gender, ethnicity, health and occupation is set out in Table 9. The method of calculating the aggregate effect of unionisation on the average pay of (say) females relative to males $\left(\Delta^{*}\right)$ is set out in Ashenfelter (1972). Approximately:

$$
\Delta *=\left(\mathrm{FP}_{\mathrm{f}}-\mathrm{MP}_{\mathrm{m}}\right)+\left(\mathrm{D}_{\mathrm{f}}-\mathrm{D}_{\mathrm{m}}\right)
$$

Where $\mathrm{F}$ is proportion of females unionised

$\mathrm{M}$ is proportion of males unionised

$\mathrm{P}_{\mathrm{f}}$ is proportionate union/non-union wage advantage of organised female labour

$\mathrm{P}_{\mathrm{m}}$ is proportionate union/non-union wage advantage of organised male labour

$D_{f}$ is proportionate effect of unionisation on the wage of non-union female workers

$\mathrm{D}_{\mathrm{m}}$ is proportionate effect of unionisation on the wage of non-union male workers

The effect of unionisation on male-female differentials is therefore composed of three separate effects. One of these is the effect of unionisation on the wages of non-union female and male workers $\left(D_{f}-D_{m}\right)$. These effects are unobservable - we know little of their size or incidence - therefore $\Delta^{*}$ - the proportionate female/male wage ratio in the presence of

\footnotetext{
1 This is approximately half the incidence of low pay calculated by the Low Pay Commission (1998). There are two main reasons why this WERS estimate is lower. First, it is plausible that lower paying (more authoritarian) managers were less likely to distribute this employee questionnaire to the selected workers. Second, and more importantly, the hourly earnings for employees is calculated by dividing information on broadly banded earnings (i.e. not actual) by actual hours. Given these possible measurement errors and nonresponse bias the evidence in Table 8 should be treated cautiously.
} 
unionism versus what it would be in the absence of unionism - cannot be estimated. What we can estimate is:

$$
\Delta \cong \Delta *-\left(\mathrm{D}_{\mathrm{f}}-\mathrm{D}_{\mathrm{m}}\right) \equiv \mathrm{FP}_{\mathrm{f}}-\mathrm{MP}_{\mathrm{m}}
$$

$\Delta$ is what can be observed and is the proportionate difference between the average female/male wage ratio of all workers relative to the female/male ratio of non-union workers. It is composed of two separate effects: the respective proportions unionised and the respective pay premiums. However, it is plausible that the effects of unionisation on nonunion wages do not differ much by gender. Hence it is reasonable to assume that $\Delta \cong \Delta^{*}$. In what follows we therefore interpret the results as the impact of unionisation on the structure of hourly earnings rather than the effect on the average (say female/male) wage ratio for all workers relative to the female/male ratio for non-union workers.

The results reported in Table 9 and Table A.5 are quite remarkable. Unionisation and collective bargaining narrow the wage structure for each pair of groups. The fraction of employees who are union members is rather similar for each of the groups set out in the table: in each case around one third of the group are union members. Thus the impact of unionisation on the pay structure comes via the premium associated with union membership. In each case the lower paid group - females, non-white, those with health problems, and manuals - receive a higher premium if they are a union member or covered by collective bargaining than do their higher paid counterpart groups ${ }^{2}$.

Consequently the average wage structure is narrowed by the following percentages compared with what it would be if there were no unions or no collective bargaining:

\begin{tabular}{|lcc|}
\hline \multicolumn{1}{|c}{ Group } & \multicolumn{2}{c|}{ If there were no } \\
& Unions & Collective bargaining \\
& Wage structure would be wider by $\%$ \\
\hline Male-female & 2.6 & 3.1 \\
White-black & 1.4 & 3.3 \\
Healthy-health problems & 0.6 & 1.2 \\
Non-manual-manual & 3.1 & 6.4 \\
\hline
\end{tabular}

It should be remembered that many people think of unions as operating to the advantage of able bodied, white male workers. Indeed, recently Frances O'Grady, Head of the TUC's New Unionism project described unions as "male, pale and stale". If this were the case the wage structure in Table 9 would be widened not compressed.

\footnotetext{
2 This paper is an exercise in industrial relations rather than econometrics. But it should be pointed out that there is some debate in the literature concerning the calculation of the union wage differential. The most thorough evaluation of the evidence has been presented by Swaffield (1999). She concludes that OLS estimates using cross section data such as that from the Labour Force Survey are modestly biased upwards because of failure to control for unobserved heterogeneity. But fixed effects estimates from panel data (not available in the LFS) are biased downwards because of measurement error. Thus there is no single best method to calculate the union differential. It is interesting and comforting to note that using both OLS and fixed effects estimation techniques Swaffield finds (1999, Table 2), like us, that the union wage differential for females is larger and more significant than it is for males.
} 
Heery (2000) points out that union success in raising the pay floor "is the primary reason why union wage bargaining generates a bigger gap for unionised women workers: women are more likely to be found in the lower reaches of the pay structure and therefore benefit more from the upward compression of earnings" (p.10). He also notes that some unions engage in 'equality bargaining' which gives priority to equal pay and equal treatment and seeks reform of pay structures which operates to the detriment of women workers. Heery cites, for example, 1990s changes to pay and grading structures to combat indirect discrimination against female employees in local government, electricity supply, banking and retailing. Unions have also sponsored women "pursuing equal pay cases against their employers through the employment tribunal system as a means of putting pressure on managers to negotiate the introduction of new job evaluation and grading procedures." These anti-gender discrimination policies by unions appear to be successful. The evidence suggests that union activity narrows the gender wage differential by some 3\% compared with what it would be in the absence of unions. This confirms Proposition 6.

The TUC recently stated (1999a) that "trade unions themselves must constantly review their effectiveness at attracting and encouraging membership amongst black workers and at providing black members with a level of service which meets their individual requirements and which also prioritises issues of discrimination". The evidence in Table 9 is presumably just what the TUC is looking for. It can point out that without unions the wage gap between whites and blacks would be between $1.4 \%$ and $3.3 \%$ greater, again confirming Proposition 6.

\section{Summary and Conclusion}

Writing four decades ago Allan Flanders (1961), the most thoughtful contemporary observer of industrial relations, stated: "trade unions can fairly be described as a 'sword of justice'. That is the continual social purpose which has fired their idealistic motivation" (p.21). He then asked: "Are they now at the end of the road?". Greatly troubled by the unions' somewhat opportunistic response to full employment he answered his rhetorical question with pessimism unions "are not making the most of their own stirring music, their great theme of the cry for justice, and by default seem only to be listening to the clinking of cash" (p.23). Flanders response was, it seems, premature. For, in this paper, we have shown:

- unionised workplaces continue to make greater use of objective pay setting criteria such as job classification and tenure, and less use of subjective merit pay, than their non-union counterparts

- although the move away from national bargaining to decentralised bargaining has caused pay dispersion to rise, workers in the organised sector have much lower pay dispersion than those in the unorganised sector.

- one reason for this is that pay in the organised sector is based more on jobs and less on individual characteristics. The return to extra human capital - experience and qualifications - is substantially lower among union members than for non-unionists.

- before there was a national minimum wage unions truncated the lower tail of the pay distribution. Therefore the incidence of low pay was much lower in unionised workplaces and among union members than in the unorganised sector.

- putting much of the above together, unions narrow the wage differentials between women and men, blacks and whites, those with health problems and those without, and between manual and non-manual workers. 
This evidence suggests that Flanders' fears that the 'sword of justice' had been blunted and corroded are unfounded. Unions remain a major egalitarian influence on the British labour market. 
Table 1

Union membership and collective bargaining coverage

$\%$ of employees

\begin{tabular}{|cc|c|c|c|}
\hline \multirow{4}{*}{} & & \multicolumn{2}{|c|}{$\begin{array}{c}\text { Coverage by } \\
\text { collective bargaining }\end{array}$} & Total \\
\cline { 3 - 5 } Union members & Yes & No & \\
\cline { 3 - 5 } & Yes & 25 & 6 & 31 \\
& No & 10 & 59 & 69 \\
\hline & Total & 35 & 65 & 100 \\
\hline
\end{tabular}

Note: Sample is 16,730 employees aged 18-59/64 excluding students for whom information exists on hourly earnings, union status and collective bargaining status. The information is weighted such that it is representative of the population of employees.

Source: Quarterly Labour Force Survey, Autumn 1998. 


\section{Table 2}

Factors influencing differences in pay levels among full-time employees in the largest occupational group within the workplace

$\%$ of workplaces

\begin{tabular}{|c|c|c|}
\hline Factor & $\begin{array}{l}\text { With union } \\
\text { recognition }\end{array}$ & $\begin{array}{l}\text { No union } \\
\text { recognition }\end{array}$ \\
\hline \multicolumn{3}{|l|}{$\underline{\text { Performance or job-based }}$} \\
\hline Performance appraisal or assessment & 18 & 37 \\
\hline Incentive or performance related pay & 22 & 27 \\
\hline Job grade / classification & 76 & 59 \\
\hline \multicolumn{3}{|l|}{$\underline{\text { Skills or qualifications }}$} \\
\hline Skills / core competencies & 35 & 55 \\
\hline Formal qualifications & 30 & 24 \\
\hline \multicolumn{3}{|l|}{$\underline{\text { Seniority and age }}$} \\
\hline Years of service & 51 & 26 \\
\hline Age of employee & 15 & 23 \\
\hline \multicolumn{3}{|l|}{$\underline{\text { Hours }}$} \\
\hline Shift premia & 27 & 19 \\
\hline Overtime & 51 & 58 \\
\hline Hours worked & 50 & 59 \\
\hline $\mathrm{n}$ & 846 & 1044 \\
\hline
\end{tabular}

Note: Weighted nationally representative sample of workplaces with $25+$ employees; managers responses, $n=1890$

Source: WERS 1998, Section F 
Table 3

Links between union recognition and use of different payment systems

\begin{tabular}{lcc}
\hline $\begin{array}{l}\text { Dependent variable: use of payment system } \\
\text { indicated below }\end{array}$ & All workplaces & $\begin{array}{c}\text { Private sector } \\
\text { workplaces }\end{array}$ \\
\hline $\begin{array}{l}\text { Individual or group performance related } \\
\text { pay schemes }\end{array}$ & -0.065 & -0.029 \\
Employee share ownership schemes & $(-2.25)$ & $(-1.00)$ \\
& - & 0.107 \\
Profit related pay schemes & - & $(3.01)$ \\
& & -0.031 \\
Any contingent pay & -0.026 & $-0.81)$ \\
$\mathrm{n}$ & $(-0.72)$ & -0.009 \\
\hline
\end{tabular}

Notes:

1. Probit equation to allow for categorical nature of dependent variable. Data in the table refer to union recognition coefficients ( $\mathrm{t}$ statistics) from the probit equation.

2. Control variables: ownership (2 categories), industry (12), size (5), establishment age, labour force characteristics (4) plus for whole sample public/private; and for private sector sample product market competition.

3. Similar statistical exercise was used replacing recognition with density and the resulting associations were very similar.

Source: WERS 1998, Section F for payment systems. 
Table 4

Union membership, pay levels and dispersion

\begin{tabular}{|c|c|c|c|c|c|c|c|c|}
\hline & \multicolumn{4}{|c|}{ Union members } & \multicolumn{4}{|c|}{ Non-union } \\
\hline & $\%$ unionised & $\begin{array}{c}\text { Mean } \\
\text { hourly } \\
\text { wage } £\end{array}$ & $\begin{array}{c}\text { Standard } \\
\text { deviation } £\end{array}$ & $\mathrm{CV}$ & $\begin{array}{c}\% \text { not } \\
\text { unionised }\end{array}$ & $\begin{array}{c}\text { Mean } \\
\text { hourly } \\
\text { wage } £\end{array}$ & $\begin{array}{c}\text { Standard } \\
\text { deviation } £\end{array}$ & $\mathrm{CV}$ \\
\hline Male & 33.0 & 9.40 & 4.59 & .488 & 67.0 & 9.10 & 7.09 & .779 \\
\hline Female & 30.8 & 8.37 & 4.03 & .482 & 69.2 & 6.25 & 4.20 & .672 \\
\hline White & 32.0 & 8.93 & 4.40 & .492 & 68.0 & 7.77 & 6.12 & .788 \\
\hline $\begin{array}{l}\text { Non- } \\
\text { white }\end{array}$ & 31.5 & 8.91 & 3.62 & .407 & 68.5 & 6.95 & 4.35 & .626 \\
\hline Healthy & 31.7 & 9.01 & 4.37 & .485 & 68.3 & 7.88 & 6.20 & .787 \\
\hline $\begin{array}{l}\text { Health } \\
\text { problems }\end{array}$ & 33.6 & 8.35 & 4.37 & .523 & 66.4 & 6.71 & 4.80 & .715 \\
\hline $\begin{array}{l}\text { Non- } \\
\text { manual }\end{array}$ & 32.1 & 10.24 & 4.74 & .463 & 67.9 & 9.32 & 7.03 & .754 \\
\hline Manual & 32.1 & 6.89 & 2.68 & .388 & 67.9 & 5.19 & 2.56 & .493 \\
\hline Total & 31.9 & 8.94 & 4.38 & .490 & 68.1 & 7.75 & 6.08 & .784 \\
\hline
\end{tabular}

Notes: Sample size is 16730 . Non-whites refer to all ethnic origin groups other than whites. Those with health problems are defined as people with a long term disability which substantially limits their day-to-day activities or affects the kind of, or amount of, work they might do.

Source: Labour Force Survey, Autumn 1998 
Table 5

Unions and the distribution of pay

\begin{tabular}{|c|c|c|c|c|c|c|c|}
\hline & & \multicolumn{3}{|c|}{ Raw } & \multicolumn{3}{|c|}{ Residuals } \\
\hline & & SD & $90-10$ & Variance & SD & $90-10$ & Variance \\
\hline \multirow{2}{*}{ Male } & Union & 0.444 & 1.11 & 0.197 & 0.367 & 0.871 & 0.135 \\
\hline & Non-union & 0.610 & 1.51 & 0.372 & 04.14 & 0.939 & 0.179 \\
\hline \multirow{2}{*}{ Female } & Union & 0.464 & 1.18 & 0.215 & 0.308 & 0.679 & 0.095 \\
\hline & Non-union & 0.521 & 1.25 & 0.272 & 0.371 & 0.815 & 0.138 \\
\hline \multirow{2}{*}{ Healthy } & Union & 0.454 & 1.14 & 0.206 & 0.327 & 0.764 & 0.107 \\
\hline & Non-union & 0.593 & 1.46 & 0.352 & 0.397 & 0.903 & 0.158 \\
\hline \multirow{2}{*}{$\begin{array}{c}\text { Health } \\
\text { problems }\end{array}$} & Union & 0.476 & 1.17 & 0.227 & 0.333 & 0.740 & 0.111 \\
\hline & Non-union & 0.570 & 1.38 & 0.325 & 0.398 & 0.900 & 0.158 \\
\hline \multirow{2}{*}{ White } & Union & 0.459 & 1.14 & 0.210 & 0.331 & 0757 & 0.109 \\
\hline & Non-union & 0.595 & 1.47 & 0.354 & 0.399 & 0.904 & 0.159 \\
\hline \multirow{2}{*}{ Non-white } & Union & 0.426 & 1.07 & 0.182 & 0.280 & 0.709 & 0.078 \\
\hline & Non-union & 0.543 & 1.40 & 0.295 & 0.353 & 0.869 & 0.124 \\
\hline \multirow{2}{*}{ Non-manual } & Union & 0.441 & 1.07 & 0.194 & 0.319 & 0.712 & 0.111 \\
\hline & Non-union & 0.603 & 1.49 & 0.363 & 0.421 & 0.939 & 0.179 \\
\hline \multirow{2}{*}{ Manual } & Union & 0.386 & 0.96 & 0.149 & 0.326 & 0.775 & 0.106 \\
\hline & Non-union & 0.430 & 1.02 & 0.185 & 0.339 & 0.769 & 0.115 \\
\hline \multirow{2}{*}{ Total } & Union & 0.457 & 1.14 & 0.209 & 0.330 & 0.768 & 0.109 \\
\hline & Non-union & 0.592 & 1.47 & 0.351 & 0.400 & 0.904 & 0.159 \\
\hline
\end{tabular}

Notes:

1. Sample size is 16730 .

2. Standard deviation, 90-10 and variance from log earnings.

3. The residuals are estimated from a regression equation containing the following independent variables: age, qualifications, workplace size, industry, marital status, public/private, full-time/part-time, permanent/temporary, gender, able bodied/disabled, ethnicity, occupation and region.

Source: Labour Force Survey, Autumn 1998. 
Table 6

Returns to human capital and workplace size

\begin{tabular}{|l|cc|cc|}
\hline \multicolumn{1}{|c|}{ Characteristics } & \multicolumn{2}{c|}{ Male } & \multicolumn{2}{c|}{ Female } \\
Age & Union & $\begin{array}{c}\text { Non- } \\
\text { union }\end{array}$ & Union & $\begin{array}{c}\text { Non- } \\
\text { union }\end{array}$ \\
\hline 25-34 & & & & \\
$35-49$ & & & & \\
$50+$ & .220 & .321 & .236 & .287 \\
Education & .370 & .484 & .290 & .325 \\
CSE/lower vocational & .362 & .458 & .307 & .339 \\
O level/intermediate vocational & & & & \\
A level/advanced vocational & .122 & .143 & .129 & .084 \\
Teaching, nursing, higher voc. & .344 & .529 & .190 & .150 \\
Degree & .427 & .530 & .332 & .269 \\
Workplace size & .641 & .738 & .757 & .399 \\
25-49 & & & & .659 \\
50+ & & & & \\
\hline
\end{tabular}

Note: Calculated from regression equations with same independent variables as set out in note 3 to Table 5. Excluded categories are: age 18-24; no education qualifications; 10-24 employees. 


\section{Table 7}

\section{Percentage of employees earning below $£ 3.50$ per hour}

\begin{tabular}{|c|c|c|c|}
\hline Union Variable & All & Full-time & Part-time \\
\hline $\begin{array}{l}\text { One or more union recognised at the workplace } \\
\qquad \text { coefficient } \\
\bullet \quad \text { marginal effect ( } \% \text { points })\end{array}$ & $\begin{array}{l}-0.14 * * \\
-3.9\end{array}$ & $\begin{array}{l}-0.13^{*} \\
-2.3\end{array}$ & $\begin{array}{l}-0.21 \\
-2.2\end{array}$ \\
\hline $\begin{array}{l}60 \% \text { plus of employees in the workplace covered by col } \\
\text { • coefficient } \\
\text { - marginal effect (\% points) }\end{array}$ & $\begin{array}{l}\text { lective bai } \\
-0.14 * * \\
-3.8\end{array}$ & $\begin{array}{l}\text { aining } \\
-0.20^{* *} \\
-3.5\end{array}$ & $\begin{array}{l}-0.18 \\
-1.9\end{array}$ \\
\hline $\begin{array}{l}\text { Any union member at the workplace but no recognition } \\
\text { - coefficient } \\
\text { - marginal effect (\% points) }\end{array}$ & $\begin{array}{l}0.09 * * \\
2.4\end{array}$ & $\begin{array}{l}0.19 * * \\
3.1\end{array}$ & $\begin{array}{l}0.03 \\
0.3\end{array}$ \\
\hline
\end{tabular}

Notes:

1. Sample is 1106 workplaces in trading sector from 1998 Workplace Employee Relations Survey which is nationally representative sample of workplaces with 10 or more employees.

2. Mean of dependent variable is: All 10.5\%, Full-time 5.6\%, Part-time 23\%.

3. Control variables

Workplace: size; public sector; how long at this address; foreign owned; industry Workforce: \% aged under 20, over 51; disabled; ethnic minority; female; part-time Product market: growing market; sales revenue grew; market share above $25 \%$; international market; many competitors; high level of competition; overseas competition

4. Tobit analysis. **significant at $1 \%$; *significant at $5 \%$

Source: McNabb and Whitfield (1999, Table 10) from 1998 Workplace Employee Relations Survey. 


\section{Table 8}

Probability that individual employee earns less than $£ 3.50$ per hour

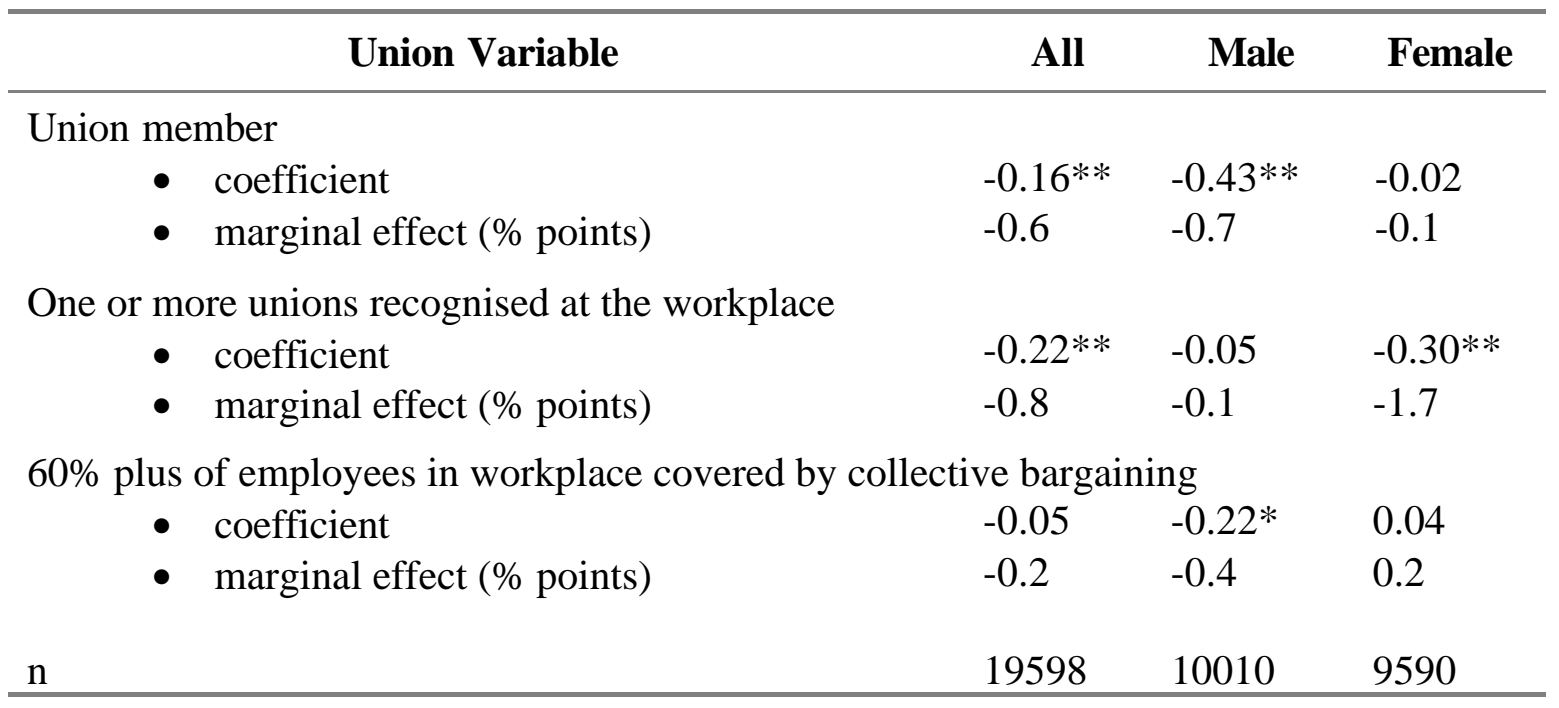

Notes:

1. Sample is 19598 individuals from 1998 workplace Employment Relations Survey. This sample is from workplaces with 25 or more employees.

2. Dependent variable is calculated by dividing banded weekly earnings by actual hours. $3.4 \%$ of sample defined as earning less than $£ 3.50$ per hour. A dummy variable $(0 / 1)$ indicates whether or not the individual is low paid.

3. Control Variables

Individual: age; qualifications; ethnic group; marital status; number of children. Job Characteristics: job tenure; job type e.g. fixed, temporary, mainly done by women.

Establishment characteristics: size of workplace; size of organisation; \% of workforce by occupation, age, disabled, ethnic minority, female PT; foreign owned; public sector; vintage.

4. probit analysis. $* *$ significant at $1 \%$, *significant at $5 \%$

Source: McNabb and Whitfield (1999, Tables 12, 13) from 1998 Workplace Employee Relations Survey. 


\section{Table 9}

Impact of unionisation on pay structure by gender, race, health and occupation

\begin{tabular}{lccc}
\hline \multicolumn{1}{c}{ Group } & $\begin{array}{c}\text { Fraction } \\
\text { unionised }\end{array}$ & Premium & $\begin{array}{c}\text { Union } \\
\text { impact } \\
\text { (Ty }\end{array}$ \\
\hline Male & .330 & -.003 & .026 \\
Female & .308 & .087 & \\
White & .320 & .039 & .014 \\
Non-white & .315 & .084 & \\
Healthy & .317 & .039 & .0055 \\
Health problems & .336 & .053 & \\
Non-manual & .321 & .030 & .031 \\
Manual & .321 & .129 & \\
\hline
\end{tabular}

Notes:

1. Total sample size is $\mathbf{1 6 4 8 9}$

2. Hourly pay premium associated with union membership estimated from regression equation with the following controls: age, marital status, qualifications, part-time worker, temporary worker, industry, public sector, workplace size, region and (as appropriate) gender, ethnicity and health.

3. In all the regressions but one the coefficient on unionisation is significant at better than $1 \%$. Further, in each pairwise comparison the premia are significantly different from one another at $5 \%$ or better: See appendix Table A.3.

Source: Labour Force Survey, Autumn 1998. 
Table A.1

Collective bargaining coverage, pay levels and dispersion

\begin{tabular}{|c|r|r|r|r|r|r|r|r|}
\hline & \multicolumn{4}{|c|}{ Covered by collective bargaining } & \multicolumn{3}{c|}{ Not covered by collective bargaining } \\
\hline & \% covered & $\begin{array}{c}\text { Mean } \\
\text { hourly } \\
\text { wage } £\end{array}$ & $\begin{array}{c}\text { Standard } \\
\text { deviation } £\end{array}$ & \multicolumn{1}{c|}{ CV } & $\begin{array}{c}\text { \% not } \\
\text { covered }\end{array}$ & $\begin{array}{c}\text { Mean } \\
\text { hourly } \\
\text { wage } £\end{array}$ & $\begin{array}{c}\text { Standard } \\
\text { deviation } £\end{array}$ & CV \\
\hline Male & 36.0 & 9.31 & 4.49 & .483 & 64.0 & 9.15 & 7.23 & .790 \\
Female & 38.2 & 7.97 & 3.95 & .495 & 61.8 & 6.26 & 4.37 & .697 \\
\hline White & 37.1 & 8.65 & 4.30 & .497 & 62.9 & 7.87 & 6.33 & .804 \\
Non-white & 37.1 & 8.95 & 3.89 & .434 & 62.9 & 6.77 & 4.28 & .603 \\
\hline Healthy & 37.0 & 8.72 & 4.27 & .490 & 63.0 & 7.98 & 6.41 & .804 \\
Health & 37.1 & 8.29 & 4.48 & .540 & 62.9 & 6.66 & 4.78 & .717 \\
\hline problems & 38.2 & 9.79 & 5.52 & .462 & 61.8 & 9.54 & 7.34 & .770 \\
\hline Non-manual
\end{tabular}

Notes: See notes to Table 4.

Source: Labour Force Survey, Autumn 1998, n=16730 
Table A.2

Collective bargaining and the distribution of pay

\begin{tabular}{|c|c|c|c|c|c|c|c|}
\hline & & \multicolumn{3}{|c|}{ Raw } & \multicolumn{3}{|c|}{ Residuals } \\
\hline & & SD & $90-10$ & Variance & SD & 90-10 & Variance \\
\hline \multirow{2}{*}{ Male } & $\begin{array}{l}\text { Covered by } \\
\text { collective bargaining }\end{array}$ & .447 & 1.13 & .200 & .365 & 0.863 & .133 \\
\hline & Not covered & .616 & 1.52 & .379 & .462 & 1.095 & .213 \\
\hline \multirow{2}{*}{ Female } & $\begin{array}{l}\text { Covered by } \\
\text { collective bargaining }\end{array}$ & .456 & 1.16 & .208 & .339 & 0.78 & .115 \\
\hline & Not covered & .538 & 1.29 & .289 & .418 & 0.935 & .175 \\
\hline \multirow{2}{*}{ Healthy } & $\begin{array}{l}\text { Covered by } \\
\text { collective bargaining }\end{array}$ & .456 & 1.17 & .208 & .356 & 0.832 & .127 \\
\hline & Not covered & .606 & 1.49 & .378 & .445 & 1.021 & .198 \\
\hline \multirow{2}{*}{$\begin{array}{l}\text { Health } \\
\text { problems }\end{array}$} & $\begin{array}{l}\text { Covered by } \\
\text { collective bargaining }\end{array}$ & .483 & 1.17 & .233 & .347 & 0.843 & .120 \\
\hline & Not covered & .572 & 1.37 & .378 & .404 & 1.008 & .163 \\
\hline \multirow[t]{2}{*}{ White } & $\begin{array}{l}\text { Covered by } \\
\text { collective bargaining }\end{array}$ & .460 & 1.17 & .211 & .354 & 0.838 & .126 \\
\hline & Not covered & .607 & 1.49 & .369 & .444 & 1.023 & .197 \\
\hline \multirow[t]{2}{*}{ Non white } & $\begin{array}{l}\text { Covered by } \\
\text { collective bargaining }\end{array}$ & .435 & 1.06 & .189 & .368 & 0.804 & .136 \\
\hline & Not covered & .547 & 1.38 & .299 & .442 & 1.031 & .195 \\
\hline \multirow[t]{2}{*}{ Non-manual } & $\begin{array}{l}\text { Covered by } \\
\text { collective bargaining }\end{array}$ & .448 & 1.12 & .200 & .345 & 0.803 & .119 \\
\hline & Not covered & .618 & 1.54 & .382 & .454 & 1.026 & .206 \\
\hline \multirow[t]{2}{*}{ Manual } & $\begin{array}{l}\text { Covered by } \\
\text { collective bargaining }\end{array}$ & .390 & 0.95 & .152 & .333 & 0.764 & .111 \\
\hline & Not covered & .434 & 1.04 & .189 & .349 & 0.809 & .122 \\
\hline \multirow[t]{2}{*}{ Total } & $\begin{array}{l}\text { Covered by } \\
\text { collective bargaining }\end{array}$ & .459 & 1.16 & .211 & .357 & 0.838 & .127 \\
\hline & Not covered & .605 & 1.48 & .366 & .445 & 1.028 & .198 \\
\hline
\end{tabular}

Notes: (i) Sample size is 16730; (ii) standard deviation, 90-10 and variance from log earnings; (iii) the residuals are estimated from a regression equation containing the following independent variables: age, qualifications, workplace size, industry, marital status, public/private, full-time/part-time,

permanent/temporary, gender, able bodied/disabled, ethnicity, occupation and region.

Source: Labour Force Survey, Autumn 1998. 
Table A.3

Union and collective bargaining hourly pay premia

\begin{tabular}{|c|c|c|c|c|c|}
\hline \multirow{2}{*}{ Group } & \multicolumn{2}{|c|}{ Union membership } & \multicolumn{2}{|c|}{ Collective bargaining } & \multirow{2}{*}{$\mathbf{n}$} \\
\hline & Raw & $\begin{array}{c}\text { With } \\
\text { Controls }\end{array}$ & Raw & $\begin{array}{c}\text { With } \\
\text { controls }\end{array}$ & \\
\hline Male & $.130(10.03)$ & $-.003(-.279)$ & $.120(9.37)$ & $-.026(-2.20)$ & 8219 \\
\hline Female & $.334(28.10)$ & $.087(7.91)$ & $.293(25.77)$ & $.057(5.11)$ & 8270 \\
\hline White & $.236(25.31)$ & $.039(4.76)$ & $.198(21.80)$ & $.011(1.27)$ & 15796 \\
\hline Non-white & $.271 \quad(6.36)$ & $.084(2.14)$ & $.283 \quad(7.03)$ & $.099(2.58)$ & 693 \\
\hline Healthy & $.231(23.90)$ & $.039(4.67)$ & $.191(20.39)$ & $.010(1.13)$ & 14657 \\
\hline Health problems & $.294(11.08)$ & $.053(2.11)$ & $.279(10.76)$ & $.042(1.63)$ & 1832 \\
\hline Non-manual & $.199(17.07)$ & $.030(2.86)$ & $.139(12.28)$ & $-.032(-2.95)$ & 10209 \\
\hline Manual & $.305(27.25)$ & $.129(11.71)$ & $.282(25.68)$ & $.146(13.12)$ & 6346 \\
\hline TOTAL & $.237(26.05)$ & $.041(5.13)$ & $.201(22.73)$ & 0.014 (1.69) & 16489 \\
\hline
\end{tabular}

Notes: Log earnings is LHS variable. Coefficients (and t values) as follows. Raw from regression containing only unionisation or collective bargaining. With controls from regression containing controls specified in Table 9.

Source: $\quad$ Labour Force Survey, Autumn 1998. 
Table A.4

Returns to human capital and workplace size

\begin{tabular}{|c|c|c|c|c|}
\hline \multirow[t]{2}{*}{ Characteristics } & \multicolumn{2}{|c|}{ Male } & \multicolumn{2}{|c|}{ Female } \\
\hline & $\begin{array}{c}\text { Collective } \\
\text { bargaining }\end{array}$ & Not covered & $\begin{array}{c}\text { Collective } \\
\text { bargaining }\end{array}$ & Not covered \\
\hline Age & & & & \\
\hline $25-34$ & .236 & .325 & .241 & .289 \\
\hline $35-49$ & .400 & .480 & .328 & .310 \\
\hline $50+$ & .388 & .454 & .358 & .316 \\
\hline Education & & & & \\
\hline CSE/lower vocational & .148 & .130 & .087 & .097 \\
\hline O level/intermediate vocational & .222 & .264 & .150 & .170 \\
\hline A level/advanced vocational & .310 & .460 & .246 & .308 \\
\hline Teaching, nursing, higher vocational & .459 & .514 & .463 & .444 \\
\hline Degree & .657 & .734 & .702 & .695 \\
\hline Workplace Size & & & & \\
\hline $25-49$ & .060 & .102 & -.017 & .047 \\
\hline $50+$ & .080 & .218 & .005 & .176 \\
\hline
\end{tabular}

Notes: See notes to Table 6. 
Table A.5

Impact of collective bargaining on pay structure by gender, race, health and occupation

\begin{tabular}{lccc}
\hline \multicolumn{1}{c}{ Group } & $\begin{array}{c}\text { Fraction } \\
\text { covered by } \\
\text { collective } \\
\text { bargaining }\end{array}$ & Premium & $\begin{array}{c}\text { Collective } \\
\text { bargaining } \\
\text { impact } \\
\text { ( TM }\end{array}$ \\
\hline Male & .360 & -.026 & .031 \\
Female & .382 & .057 & \\
White & .371 & .011 & .033 \\
Non-white & .371 & .099 & \\
Healthy & .370 & .010 & .012 \\
Health problems & .371 & .042 & \\
Non-manual & .382 & -.032 & .064 \\
Manual & .357 & .146 & \\
\hline
\end{tabular}

Notes and sources: See Table 9. 


\section{References}

Ashenfelter, O. and Johnson, G. (1972) 'Racial Discrimination and Trade Unions', Journal of Political Economy, Vol.80, No.3, Part I May/June.

Bell, B. and Pitt, M. (1998) 'Trade Union Decline and the Distribution of Wages in the UK: Evidence from Kernel Density Estimation', Oxford Bulletin of Economics and Statistics, Vol.60(4), pp.509-528.

Bland, P. (1999) 'Trade Union Membership and Recognition 1997-98: An Analysis of Data from the Certification Officer and the Labour Force Survey', Labour Market Trends, July, pp.343-351.

Blau, F. and Khan, L. (1996) 'International Differences in Male Wage Inequality: Institutions Versus Market Forces', Journal of Political Economy, Vol.104 (4), pp.791-837.

Booth, A. and Frank, J. (1999) 'Earnings, Productivity and Performance-Related Pay', Journal of Labor Economics, Vol.17(3), pp.447-463.

British Chamber of Commerce (1999) National Minimum Wage Survey, October.

Brown, W., Deakin, S., Hudson, M., Pratten, C. and Ryan, P. (1998) 'The Individualisation of Employment Contracts in Britain', Research Paper, Department of Trade and Industry.

Brown, W. and Walsh, J. (1991) 'Pay Determination in Britain in the 1980's: the Anatomy of Decentralisation', Oxford Review of Economic Policy, Vol.7(1) Spring, pp.44-59.

Burgess, S. and Metcalfe, P. (1999) 'The Use of Incentive Schemes in the Public and Private Sectors: Evidence from British Establishments', University of Bristol, mimeo, November.

Clegg,H. (1970) The System of Industrial Relations in Great Britain, Basil Blackwell: Oxford.

Communication Workers Union (1999) Performance-Related Pay - Panacea or Pain? CWU Internal Policy Document.

Confederation of Shipbuilding and Engineering Unions (1999) $61^{\text {st }}$ Annual Meeting Agenda and Reports.

Cully, M. and Woodland, S. (1998) 'Trade Union Membership and Recognition 1996-97: An Analysis of Data from the Certification Officer and the LFS', Labour Market Trends, July, pp.353- 364 .

Cully, M., Woodland, S., Reilly, A. and Dix, G. (1999) Britain at Work, Routledge: London.

Cully, M and six others (1998) The 1998 Workplace Employee Relations Survey, First Findings, Department of Trade and Industry. 
Fernie, S. and Metcalf, D. (1999) 'Not Hanging on the Telephone', Advances in Industrial and Labor Economics, Vol.9, pp.23-68.

Flanders, A. (1961) 'Trade Unions in the Sixties', Socialist Commentary, August.

Flanders, A. (1970) Management and Unions: The Theory and Reform of Industrial Relations, Faber: London.

Freeman, R. (1980) 'Unionism and the Dispersion Of Earnings', Industrial and Labor Relations Review, Vol.34 (1), October, pp.3-23.

Freeman, R. (1982) 'Union Wage Practices and Wage Dispersion Within Establishments', Industrial and Labor Relations Review, Vol.36(1), October, pp.3-18.

Freeman, R. and Medoff, J. (1984) What Do Unions Do? Basic Books: New York.

Gosling, A. and Machin, S. (1995) 'Trade Unions and the Dispersion Of Earnings In UK Establishments 1980-90' Oxford Bulletin of Economics and Statistics, Vol.57(2), pp.167-184.

Gospel, H. and Drucker, J. (1998) 'The Survival of National Bargaining in the Electrical Contracting Industry: A Deviant Case', British Journal of Industrial Relations, Vol.36(2), June, pp.249-267.

Green, F., Machin, S. and Manning, A. (1996) 'The Employer Size-Wage Effect: Can Dynamic Monopsony Provide an Explanation?', Oxford Economic Papers, Vol.48, pp.433-455.

Heery, E. (2000) 'Trade Unions and the Management of Reward' in G. White and J. Drucker (eds), Reward Management: Critical Perspectives, Routledge.

Heery, E. and Warhurst, J. (1994) 'PRP and Trade Unions: Impact and Responses', Kingston University Business School, Occasional Paper.

Jackson, M.P., Leopold, J.W. and Tuck, K. (1993) Decentralization of Collective Bargaining: an Anaylsis of Recent Experience in the UK, Macmillan: Basingstoke.

Kelly, J. and Heery, E. (1994) Working for the Union: British Trade Union Officers, Cambridge University Press: Cambridge.

Kessler, S.and Bayliss, F. (1995) Contemporary British Industrial Relations, Macmillan: London.

Lazear, E. (1986) 'Salaries and Piece Rates', Journal of Business, Vol.59, pp.405-431.

Local Government Association (1997) Evidence to Low Pay Commission, London, 2 October. 
Machin, S. (1999) 'Pay Inequality in the 1970s, 1980s and 1990s', in P. Gregg and J. Wadsworth, (eds), The State of Working Britain, Manchester University Press.

McNabb, R. and Whitfield, K. (1999) Low Pay in Britain: Analyses Using the 1998 WERS. Report to Low Pay Commission, July.

Metcalf, D. (1982) 'Unions and the Distribution of Earnings', British Journal of Industrial Relations, Vol.16(2), July, pp.163-169.

Metcalf, D. (1999) 'New Labor's Industrial Relations Policy', Perspectives on Work, Vol.3(2), June.

Pendleton, A., Robinson, P. and Wilson, D. (1995) 'Does Employee Ownership Weaken Trade Unions? Recent Evidence from the UK Bus Industry', Economic and Industrial Democracy, Vol.16.

Phelps Brown, H. (1990) 'The Counter Revolution of Our Time', Industrial Relations, Vol.29(1), pp.1-14.

Rosyth Royal Dockyard (1992) Procedural Agreement for Industrial Employees.

Slichter, S., Healy, J. and Livernash, R. (1960) The Impact of Collective Bargaining on Management, The Brookings Institution: Washington DC.

Swaffield, J. (1999) ' Does Measurement Error Bias Fixed-Effects Estimates of the Union Wage Effect?' CEP, LSE, mimeo, September.

Trade Union Congress (1999a), Today's Trade Unionists, Economic and Social Affairs Directorate, May.

Trade Union Congress (1999b) TUC Evidence to Low Pay Commission, October 1999.

TGWU (1997) Submission to the Low Pay Commission, London, 2 October.

UNISON (1997) Submission to the Low Pay Commission, London, 2 October.

USDAW (1997) The Minimum Wage, Evidence to the Low Pay Commission, October.

Webb, S. and Webb, B. (1902) Industrial Democracy, Longmans: London. 